\title{
CHARACTERISTICS OF ANTENATAL CARE FOR ADOLESCENTS FROM STATE CAPITALS IN SOUTHERN AND NORTHEASTERN BRAZIL ${ }^{1}$
}

\author{
Rita Fernanda Monteiro Fernandes², Sonia Maria Könzgen Meincke ${ }^{3}$,Elaine Thumé4, Marilu Correa Soares ${ }^{5}$, \\ Neusa Collet ${ }^{6}$, Telma Elisa Carraro ${ }^{7}$
}

${ }^{1}$ Paper taken from the dissertation - Prenatal care in adolescence, presented to the School of Nursing at Universidade Federal de Pelotas (UFPel), in 2011. This study is an excerpt from a multicenter research entitled - Social support networks for fatherhood during adolescence, coordinated by the School of Nursing at UFpel in partnership with Universidade Federal da Paraíba (UFPB) and Universidade Federal de Santa Catarina (UFSC), under CNPq funding 551222/2007.

${ }^{2}$ M.Sc. in Nursing. Intensive Care Nursing Specialist. Pelotas, Rio Grande do Sul, Brazil. E-mail: feunipampa@hotmail.com

${ }^{3}$ Ph.D. in Nursing. Adjunct Professor at School of Nursing, UFPel. Pelotas, Rio Grande do Sul, Brazil. E-mail: meincke@ terra.com.br

${ }^{4}$ Ph.D. in Epidemiology. Adjunct Professor at School of Nursing, UFPel. Pelotas, Rio Grande do Sul, Brazil. E-mail: elainethume@ gmail.com

${ }^{5}$ Ph.D. in Public Health Nursing. Adjunct Professor at School of Nursing, UFPel. Pelotas, Rio Grande do Sul, Brazil. E-mail: enfmari@uol.com.br

${ }^{6}$ Ph.D. in Nursing. Faculty at UFPB. Joao Pessoa, Paraíba, Brazil. E-mail: neucollet@gmail.com

${ }^{7}$ Ph.D. in Nursing. Faculty, Nursing Department and Graduate Program at UFSC. Florianópolis, Santa Catarina, Brazil. E-mail: telmacarraro@ccs.ufsc.br

\begin{abstract}
Quantitative and descriptive study that intended to describe some aspects of antenatal care for adolescents at teaching hospitals in the South and Northeast of Brazil, based on the quality criteria established by the Humanization Program of Antenatal and Birth Care. This is an excerpt from the research "Social support networks for fatherhood during adolescence". The data collection occurred between December 2008 and December 2009. The sample consisted of 559 puerperal adolescents. The results showed that $98 \%$ of the interviewees received antenatal care, $67.2 \%$ attended six or more consultations and $62.5 \%$ started the care in the first pregnancy terms. As regards the routine exams, not all of them were done, and $41.8 \%$ denied having received any kind of information about labor and delivery during the antenatal consultations. In conclusion, most of the adolescents received antenatal care according to the criteria recommended in the Program. Nevertheless, educational actions and orientations are needed during the consultations.
\end{abstract}

DESCRIPTORS: Pregnancy in adolescence. Humanizing delivery. Nursing.

\section{CARACTERÍSTICAS DO PRÉ-NATAL DE ADOLESCENTES EM CAPITAIS DAS REGIÕES SUL E NORDESTE DO BRASIL}

RESUMO: Estudo quantitativo descritivo, que objetivou descrever alguns aspectos da atenção pré-natal de adolescentes em hospitais de ensino da Região Sul e Nordeste do Brasil, com base nos critérios de qualidade do Programa de Humanização do Pré-natal e Nascimento. É um recorte da pesquisa "Redes sociais de apoio à paternidade na adolescência". A coleta dos dados ocorreu de dezembro de 2008 a dezembro de 2009. A amostra constitui-se de 559 puérperas adolescentes. Os resultados evidenciaram que $98 \%$ das pesquisadas realizaram pré-natal, 67,2\% frequentaram seis ou mais consultas e $62,5 \%$ iniciaram no $1^{\circ}$ trimestre gestacional. Quanto aos exames de rotina, nem todos foram realizados e $41,8 \%$ negaram ter recebido informações sobre o trabalho de parto e parto durante as consultas pré-natais. Conclui-se neste estudo que a maioria das adolescentes realizou pré-natal conforme os critérios preconizados pelo Programa, porém, há necessidade de ações educativas e orientações durante as consultas.

DESCRITORES: Gravidez na adolescência. Parto humanizado. Enfermagem.

\section{CARACTERÍSTICAS DEL PRENATAL DE ADOLESCENTES EN CAPITALES DE LAS REGIONES SUR Y NORDESTE DE BRASIL}

RESUMEN: Estudio cuantitativo descriptivo que objetivó describir algunos aspectos de la atención prenatal de adolescentes en hospitales de enseñanza de la región Sur y Nordeste de Brasil, basado en los criterios de calidad del Programa de Humanización del Prenatal. Es un recorte de la investigación "Redes sociales de apoyo a la paternidad en la adolescencia”. La colecta de los datos ocurrió de diciembre de 2008 a diciembre de 2009. La muestra se constituyó de 559 puérperas adolescentes. Los resultados evidenciaron que $98 \%$ de las pesquisadas realizaron prenatal, 67,2\% frecuentaron seis o más consultas médicas y $62,5 \%$ empezaron en el primer trimestre de gestación. Cuanto a los análisis de rutina, ni todos fueron realizados y $41,8 \%$ negaron haber recibido informaciones acerca del trabajo de parto y parto durante las consultas prenatales. Se concluye que la mayoría de las adolescentes realizó el prenatal conforme los criterios preconizados por el Programa, pero todavía hacen falta acciones educativas y orientaciones durante las consultas.

DESCRIPTORES: Embarazo en la adolescencia. Parto humanizado. Enfermería. 


\section{INTRODUCTION}

Antenatal care includes a set of care focused on maternal and fetal health, permitting appropriate actions and orientations for women to live their pregnancy and delivery in a positive and enriching manner, reducing the risks of delivery and puerperal complications. ${ }^{1}$ Most health problems of pregnant women can be avoided, detected or treated through antenatal consultations. Antenatal care permits reaching pregnant women with multiple interventions, which can be vital to the mother and infant's wellbeing. ${ }^{2}$

In Brazil, to improve antenatal care, in 2000, the Ministry of Health ${ }^{1}$ proposed the Humanization Program of Antenatal and Birth Care (PHPN), which sets directives and guiding principles, highlighting the early contact, educational actions, supply of routine tests and orientation on the puerperal woman's return to the health service for the puerperal consultation within 42 days after birth. This Program was based on the analyses of the pregnant women, infants and postpartum women's specific care needs, in the attempt to reduce the high maternal and perinatal morbidity and mortality rates. ${ }^{1-3}$

When considering adolescent pregnancy, it is highlighted that, although early pregnancy rates have been dropping in recent years, the country still displays high levels. In Brazil, one out of every five children born comes from an adolescent mother. ${ }^{4}$

Authors mention the biological risks of adolescent pregnancy, such as spontaneous abortion, premature birth, low birth weight, problems for the mother and child's health, risks during delivery and maternal mortality. ${ }^{5-8}$ Therefore, if the adolescent pregnant woman received appropriate antenatal care, this will have a positive impact and can minimize possible disadvantages typical of her young age. ${ }^{9}$ This evidences the importance of comprehensive and problem-solving antenatal care during pregnancy, mainly for the adolescents attended in public teaching services. The findings can support continuing education programs, with a view to qualifying the work process at the institutions. The objective in this study was to get to know the demographic and socioeconomic profile of the adolescent puerperal women attended in public teaching hospitals and investigate whether the quality of the antenatal care related to the access to consultations and accomplishment of complementary tests attends to the standards set in the PHPN.

\section{METHOD}

Quantitative and descriptive study, undertaken at three obstetric services of teaching hospitals in the cities of Pelotas-RS, Florianópolis-SC and João Pessoa-PB, between December 2008 and December 2009.

The study is part of the multicenter research called Social support networks for fatherhood during adolescence (RAPAD), funded by the National Council for Scientific and Technological Development (CNPq).

The convenience sample consisted of 559 adolescent puerperal women who gave birth at the hospitals mentioned. Any puerperal women with some kind of severe pathology that would interfere in communication, making it impossible for them to answer the questionnaire. The same was true for cases of fetal death.

The variables selected for this analysis, through documentary analysis, based on the quality criteria established in the PHPN, were: received antenatal care during this pregnancy (yes; no), number of consultations (none; between one and five consultations; six or more consultations), start of antenatal care (first term; second term; third term), took tests during the pregnancy (yes; no), tests taken (urine test; anti-HIV; fasting glucose; serology for syphilis/VDRL; complete blood count; blood typing), and information and educational actions during antenatal consultations.

To identify the adolescent puerperal women, all hospital charts were reviewed to detect the adolescent mothers. After clarifying doubts and giving advice about the study, the signing of the Free and Informed Consent Form was requested and an instrument was applied to the puerperal adolescents. Besides the interview with the adolescents, data were collected from the pregnant woman's antenatal card. The instruments were coded and reviewed, followed by double data entry and analysis in the software EPI-INFO 6.04 to detect errors and preserve the reliability of the data.

Descriptive statistics were used for data analysis, including the distribution of proportions for categorical variables.

The RAPAD research project received approval from the Ethics Committee at the School of Dentistry of Universidade Federal de Pelotas, under Opinion 007/2008. 


\section{RESULTS AND DISCUSSION}

The data were grouped into demographic and socioeconomic characteristics and data related to antenatal care during the adolescent pregnancy, based on the quality criteria established by the PHPN.

The city of Pelotas-RS was the place with the highest prevalence of adolescent pregnancy, totaling $21.4 \%$ of all births at the hospital that participated in the research, followed by Florianópolis-SC, 16.2\% and João Pessoa-PB, 12.9\%. The predominant age was between 15 and 19 years, but puerperal girls of 12 years of age were interviewed at the three cities that participated in the study. As regards the skin color, about half were white (Table 1), but six adolescents in Florianópolis could not answer their skin color. Concerning the marital status, the majority was married or lived with their partner at the time of the interview, similar to the findings in other studies. ${ }^{10-11}$ Living with a partner or being married represents a risk factor for repeated adolescent pregnancy. ${ }^{12}$

What education is concerned, $64.6 \%$ had between zero and eight years of education, corresponding to primary education (Table 1). Most of the investigated adolescents therefore had a low education level, considering that, in the predominant age range (15-19 years), they should be taking secondary education. Only one puerperal adolescent in Florianópolis was in higher education. In addition, two thirds of all adolescents interviewed indicated they had dropped out of school, similar to other studies. ${ }^{11-13}$ When asked about why they were not studying, the current pregnancy was appointed as the main cause of school drop-out in $40.1 \%$ of the interviewees, followed by $20.8 \%$ out of their own free will, $11 \%$ for family reasons and $9.4 \%$ because they had already concluded secondary education.

Table 1 - Sociodemographic characteristics of puerperal adolescents $(n=559)$. RAPAD, Brazil, 2008-2009

\begin{tabular}{|c|c|c|c|c|c|c|c|c|}
\hline \multirow{2}{*}{ Variable } & \multicolumn{2}{|c|}{ Pelotas } & \multicolumn{2}{|c|}{ Florianópolis } & \multicolumn{2}{|c|}{ João Pessoa } & \multicolumn{2}{|c|}{ Total } \\
\hline & $\mathbf{n}$ & $\%$ & $\mathbf{n}$ & $\%$ & $\mathbf{n}$ & $\%$ & $\mathbf{n}$ & $\%$ \\
\hline \multicolumn{9}{|l|}{ Age } \\
\hline 10 to 14 years & 9 & 5.0 & 9 & 3.1 & 5 & 5.8 & 23 & 4.1 \\
\hline 15 to 19 years & 172 & 95.0 & 283 & 96.9 & 81 & 94.2 & 536 & 95.9 \\
\hline \multicolumn{9}{|l|}{ Skin color } \\
\hline White & 110 & 60.8 & 148 & 51.7 & 21 & 24.4 & 279 & 50.5 \\
\hline Non white & 71 & 39.2 & 138 & 48.3 & 65 & 75.6 & 274 & 49.5 \\
\hline \multicolumn{9}{|l|}{ Marital status } \\
\hline Single & 42 & 23.2 & 60 & 20.5 & 14 & 16.3 & 116 & 20.7 \\
\hline Married or with partner & 139 & 76.8 & 231 & 79.1 & 71 & 82.5 & 441 & 78.9 \\
\hline Separated/widowed & - & - & 1 & 0.4 & 1 & 1.2 & 2 & 0.4 \\
\hline \multicolumn{9}{|l|}{ Studies } \\
\hline Yes & 35 & 19.3 & 87 & 29.8 & 24 & 27.9 & 146 & 26.1 \\
\hline No & 146 & 80.7 & 205 & 70.2 & 62 & 72.1 & 413 & 73.9 \\
\hline \multicolumn{9}{|l|}{ Full years of education } \\
\hline Between 0 and 4 years & 24 & 13.3 & 7 & 2.4 & 6 & 7.0 & 37 & 6.6 \\
\hline Between 5 and 8 years & 114 & 63.0 & 164 & 56.2 & 46 & 53.5 & 324 & 58.0 \\
\hline$\geq 9$ years & 43 & 23.7 & 121 & 41.4 & 34 & 39.5 & 198 & 35.4 \\
\hline \multicolumn{9}{|l|}{ Work } \\
\hline Yes & 9 & 5.0 & 53 & 18.2 & 8 & 9.3 & 70 & 12.5 \\
\hline No & 172 & 95.0 & 239 & 81.8 & 78 & 90.7 & 489 & 87.5 \\
\hline \multicolumn{9}{|c|}{ Main source of income of puerperal adolescent } \\
\hline Employment & 3 & 1.7 & 42 & 14.4 & 07 & 8.2 & 52 & 9.3 \\
\hline Partner's income & 101 & 55.8 & 155 & 53.1 & 46 & 53.5 & 302 & 54.0 \\
\hline Family income & 61 & 33.7 & 87 & 29.8 & 29 & 33.7 & 177 & 31.7 \\
\hline Alimony & 11 & 6.1 & 6 & 2.0 & 2 & 2.3 & 19 & 3.4 \\
\hline Other income sources & 5 & 2.7 & 2 & 0.7 & 2 & 2.3 & 9 & 1.6 \\
\hline \multicolumn{9}{|l|}{ Family income* } \\
\hline$<1$ minimum wage & 38 & 22.7 & 16 & 6.3 & 27 & 37.5 & 81 & 16.5 \\
\hline 1 to 3 minimum wages & 121 & 72.5 & 157 & 62.1 & 33 & 45.8 & 311 & 63.2 \\
\hline 3.1 to 5 minimum wages & 6 & 3.6 & 55 & 21.7 & 10 & 13.9 & 71 & 14.4 \\
\hline
\end{tabular}

* 67 of all interviewees did not know the monthly family income. 
In the total group of puerperal adolescents, $87.5 \%$ indicated they were not working (Table 1 ), similar to other findings. ${ }^{10,13}$

As regards the socioeconomic characteristics, it is highlighted that, in 54\%, the interviewed adolescents' main income source was the husband/ partner, similar to the data found in another research, ${ }^{12}$ and $31.7 \%$ lived from the family income.

In addition, $16.5 \%$ of all interviewees had a monthly family income inferior to one minimum wage and $63.2 \%$ between one and three minimum wages. The city of João Pessoa-PB stood out because of the higher prevalence of puerperal adolescents who lived on a monthly family income of less than one minimum wage, while Florianópolis showed the largest number of puerperal adolescents with an income of more than three minimum wages. The adolescents' socioeconomic situation indicates that they belong to the lower middle class. Earlier studies evidenced these findings. ${ }^{10,12,14}$ Poverty and social exclusion should be considered as causes as well as consequences of early pregnancy. ${ }^{13,15}$

Table 2 - Data on antenatal care of puerperal adolescents, according to the quality criteria of the PHPN (n=559). RAPAD, Brazil, 2008-2009

\begin{tabular}{lcccccccc}
\hline \multicolumn{1}{c}{ Variable } & \multicolumn{2}{c}{ Pelotas } & \multicolumn{2}{c}{ Florianópolis } & \multicolumn{2}{c}{ João Pessoa } & \multicolumn{2}{c}{ Total } \\
\cline { 2 - 9 } & $\mathbf{n}$ & $\%$ & $\mathbf{n}$ & $\%$ & $\mathbf{n}$ & $\%$ & $\mathbf{n}$ & $\%$ \\
\hline $\begin{array}{l}\text { Number of prenatal consultations } \\
\quad\end{array}$ & 4 & 2.2 & 6 & 2.1 & 1 & 1.2 & 11 & 2 \\
$\quad$ None & 42 & 23.2 & 107 & 36.6 & 23 & 26.7 & 172 & 31 \\
$\quad$ Between 1 and 5 consultations & 135 & 74.6 & 179 & 61.3 & 62 & 72.1 & 376 & 67 \\
$\quad$ 6 or more consultations & & & & & & & & \\
Start of antenatal care & 96 & 58.2 & 174 & 61.3 & 64 & 75.3 & 334 & 63 \\
$\quad 1^{\text {st term }}$ & 60 & 36.4 & 94 & 33.1 & 17 & 20 & 171 & 32 \\
$\quad 2^{\text {nd }}$ term & 9 & 5.4 & 16 & 5.6 & 4 & 4.7 & 29 & 5.5 \\
$\quad 3^{\text {rd }}$ term & & & & & & & & \\
Place of antenatal care* & 115 & 65 & 249 & 87.1 & 49 & 57.6 & 413 & 75 \\
$\quad$ Primary Care service & 60 & 33.9 & 26 & 9.1 & 43 & 50.6 & 129 & 24 \\
$\quad$ Hospital & 4 & 2.3 & 3 & 1 & - & - & 7 & 1.3 \\
$\quad$ Health insurance & 5 & 2.8 & 6 & 2.1 & 4 & 4.7 & 15 & 2.7 \\
$\quad$ Private & 12 & 6.8 & 16 & 5.6 & 1 & 1.2 & 29 & 5.3 \\
$\quad$ Other places
\end{tabular}

* In the total group of puerperal adolescents who received antenatal care $(n=548), 45$ attended more than one place, which is why the sum is always higher than $100 \%$.

In the total group of interviewees, $98 \%$ attended antenatal consultations. Similar results were found in another study. ${ }^{11}$

As regards the number of antenatal consultations, $67.2 \%$ of the puerperal adolescents received six or more consultations, according to the Ministry of Health recommendations, and the majority attended the primary healthcare service (UBS). The city of Pelotas-RS stands out because of the high prevalence of adolescents who attended six or more antenatal consultations (Table 2).

On the opposite, in a study ${ }^{16}$ that assessed the implementation of the PHPN in 2001 and 2002, it was verified that about $20 \%$ of the women attended six antenatal consultations in the two years studied. The same authors indicate that the percentage of at least six consultations per woman remains very low, indicating that attending six consultations remains a challenge for antenatal care.

Another study ${ }^{6}$ undertaken in Montes Claros-MG, in which the antenatal care of adult and adolescents pregnant women was compared, also showed high proportions of inappropriate antenatal care, with variations according to the maternal age. The authors consider that inappropriate antenatal care, with less than six consultations, led to an increased chance of premature birth and low birth weight among the adolescent mothers. In the city of São Paulo, the prevalence corresponded to $65.5 \%$, similar to the present study findings. ${ }^{11}$ The number of prenatal consultations does not guarantee the quality of care though. ${ }^{17}$

It is emphasized that, according to the PHPN, the pregnant woman is recommended to 
start antenatal care in the first term of the pregnancy cycle. Differently from other study findings, this study indicated that $62.5 \%$ of all adolescents started antenatal monitoring early, that is, while still in the first pregnancy term.

Among the adolescents who received antenatal care, 14 could not answer in what period of the pregnancy they started the antenatal care and this information was not registered on the antenatal card. Some authors indicate, however, that the adolescent mothers start their antenatal care late and correlate the adherence to antenatal care with the quality of care delivered by health professionals and services. ${ }^{10,13}$

Table 3 - Data related to the tests during antenatal care for puerperal adolescentes according to the quality criteria of the PHPN (n=548). RAPAD, Brasil, 2008-2009

\begin{tabular}{|c|c|c|c|c|c|c|c|c|}
\hline \multirow[t]{2}{*}{ Variable } & \multicolumn{2}{|c|}{ Pelotas } & \multicolumn{2}{|c|}{ Florianópolis } & \multicolumn{2}{|c|}{ João Pessoa } & \multicolumn{2}{|c|}{ Total } \\
\hline & $\mathbf{n}$ & $\%$ & $\mathbf{n}$ & $\%$ & $\mathbf{n}$ & $\%$ & $\mathbf{n}$ & $\%$ \\
\hline \multicolumn{9}{|l|}{ Took tests during antenatal care } \\
\hline Yes & 176 & 99.4 & 282 & 98.6 & 85 & 100.0 & 543 & 99.1 \\
\hline No & 1 & 0.6 & 4 & 1.4 & - & - & 5 & 0.9 \\
\hline \multicolumn{9}{|l|}{ Test taken $(n=543)$} \\
\hline Urine type I & 143 & 81.2 & 257 & 91.1 & 74 & 87.1 & 474 & 87.3 \\
\hline Anti-HIV & 145 & 82.4 & 269 & 95.4 & 78 & 91.8 & 492 & 90.6 \\
\hline Glucose & 143 & 81.2 & 251 & 89.0 & 72 & 84.7 & 466 & 85.8 \\
\hline Serology against syphilis (VDRL) & 134 & 76.1 & 257 & 91.1 & 62 & 72.9 & 453 & 83.4 \\
\hline COOMBS & 17 & 9.7 & 25 & 8.9 & 11 & 12.9 & 53 & 9.8 \\
\hline Toxoplasmosis & 126 & 71.6 & 230 & 81.6 & 47 & 55.3 & 403 & 74.2 \\
\hline Complete blood count & 144 & 81.8 & 263 & 93.3 & 76 & 89.4 & 483 & 88.9 \\
\hline Blood typing & 136 & 77.3 & 254 & 90.1 & 75 & 88.2 & 465 & 85.6 \\
\hline Hepatitis B & 137 & 77.8 & 236 & 83.7 & 56 & 65.9 & 429 & 79.0 \\
\hline Cytopathological cervix screening & 37 & 21.0 & 76 & 26.9 & 29 & 34.1 & 142 & 26.1 \\
\hline Obstetric ultrasound & 138 & 78.4 & 203 & 72.0 & 74 & 87.1 & 415 & 76.4 \\
\hline Others* & 31 & 17.6 & 183 & 64.9 & 23 & 27.1 & 237 & 43.6 \\
\hline \multicolumn{9}{|c|}{ Received orientations about the tests requested } \\
\hline Yes & 130 & 73.9 & 246 & 87.2 & 66 & 77.6 & 442 & 81.4 \\
\hline No & 46 & 26.1 & 36 & 12.8 & 19 & 22.4 & 101 & 18.6 \\
\hline
\end{tabular}

* The other tests taken included: rubella, Hepatitis C, Cytomegalovirus, TSH, Stool test, Bilirubin, TGO-TGP, HPV, Vaginal secretion and Platelets.

Based on the data available in Table 3, almost all adolescents took the tests recommended during antenatal care. For the five adolescents who reported not having taken tests during antenatal monitoring, the reasons were justified as difficulty to access the health system and/or the health professional requested the test, but the adolescent did not take it.

The accomplishment of some basic tests serves as a quality marker of the PHPN. According to the program, a fundamental criterion for antenatal monitoring is the request of the following tests: Blood group and Rh factor; serology for syphilis; urine type I; blood count $(\mathrm{Hb} / \mathrm{Ht})$; fasting glucose and anti-HIV test with pretest counseling and the woman's consent. ${ }^{3}$ In this study, practically $90 \%$ of the interviewees took the basic tests recommended by the Ministry of Health. The antiHIV test was the most prevalent test among the puerperal adolescents, going against the findings in a study that indicated that only about $40 \%$ of the pregnant women took the anti-HIV test. ${ }^{16} \mathrm{As}$ to the blood count, recommended for all pregnant women to detect and prevent anemia, $88.9 \%$ took this test. According to the United Nations, pregnant adolescents are more prone to the development of anemia than older women, and normally receive less care. ${ }^{2}$

Only $26.1 \%$ of the interviewed adolescents reported having collected the pap smear, which can be included in the routine antenatal tests. Two-thirds submitted to an obstetric ultrasound. In a research developed at the General Hospital of the Universidade de Caxias do Sul, the rates were higher, with $51 \%$ of the interviewed pregnant women having taking the cytopathology test and $96.8 \%$ the ultrasound during pregnancy. ${ }^{10}$ Regarding information about the tests requested, most of 
the puerperal women mentioned having received some type of information.

As regards the receipt of information about delivery and birth during the antenatal consultations, $41.8 \%$ denied having received any. Among those who did, $15 \%$ indicated that the orientations received did not help them during delivery and birth. Twenty-five percent considered that the main reason was the lack of clarity in the information received, $18.7 \%$ the short length of the consultation, $8.3 \%$ that the attending health professional did not provide orientations and $8.3 \%$ mentioned receiving a lot of information at the same time, without understanding it.

The Ministry of Health ${ }^{1}$ has highlighted the importance of educational activities during antenatal monitoring. The level of information, both during the pregnancy and during labor and birth, is very relevant for the women, as it permits greater participation in the decision process and enhances their perceived control over the situation, influencing the satisfaction with the delivery. ${ }^{18}$ Pregnancy care, when mediated by dialogue and respect between the health professionals and the pregnant women, represents the first step towards humanized birth. ${ }^{19}$ Nevertheless, only a limited number of women receive appropriate antenatal care. ${ }^{16}$ The health professionals' insensitivity, the lack of information, insecurity and fear end up producing frustrations in the pregnant women. ${ }^{20}$

Antenatal care should be an educational space, as it allows the pregnant adolescents to express their fears, doubts and anguish, permitting clarifications and orientations about the pregnancy-puerperal cycle.

\section{FINAL CONSIDERATIONS}

Pregnancy is a unique phenomenon that is specific to each woman, whether adolescent or not. Therefore, antenatal care during adolescence is extremely important to advise the mothers on pregnancy care, the signs and symptoms of the onset of labor, birth and the puerperal period.

Based on the results found, it is concluded that most of the puerperal adolescents studied in this research received antenatal care, which started in the first pregnancy term with six or more consultations and the basic tests, according to the Ministry of Health's recommendations in the PHPN. On the opposite, practically half of the puerperal adolescents indicated they did not receive any type of educational information about delivery and birth during the antenatal consultations, which suggests that the professionals are unprepared to attend to these pregnant girls, despite the Ministry of Health programs, proposals and dissemination.

In that context, antenatal care deserves special emphasis in maternal and child health care, as an important factor in public health. It is fundamental for the pregnant women to receive high-quality care in compliance with all SUS principles, i.e. integrality, equity and universality, thus minimizing the risks and complications they may suffer during this period.

\section{REFERENCES}

1. Ministério da Saúde (BR). Portaria n. 569/GM de 1 de junho de 2000 que institui o Programa de Humanização no Pré-natal e Nascimento - PHPN, no âmbito do Sistema Único de Saúde, Brasília (DF): MS; 2000.

2. United Nations Children's Fund (UNICEF). Situação Mundial da Infância 2009. Saúde Materna e Neonatal. New York (US): UNICEF; 2008.

3. Ministério da Saúde (BR). Manual técnico pré-natal e puerpério: atenção qualificada e humanizada. Brasília (DF): Departamento de Ações Programáticas Estratégicas; 2006.

4. Ministério da Saúde [pagina na internet]. Departamento de Informática do SUS. Sistema de Informações de Nascidos Vivos - SINASC. Brasília (DF): DATASUS; 2009 [acesso 2011 Set 05]. Disponível em: http:/ / www2.datasus.gov.br/DATASUS/index. php?area $=0205 \& V O b j=$ http:/ / tabnet.datasus.gov . $\mathrm{br} / \mathrm{cgi} /$ deftohtm.exe?sinascp/cnv/nv

5. Vitalle MSS, Amancio OMS. Gravidez na adolescência [online]. 2004 [acesso 2012 Nov 17]. Disponível em: http://www.pjpp.sp.gov.br/2004/artigos/11.pdf

6. Goldenberg P, Figueiredo MCT, Silva RS. Gravidez na adolescência, pré-natal e resultados perinatais em Montes Claros, Minas Gerais, Brasil. Cad Saúde Pública. 2005 Jul-Ago; 21(4):1077-86.

7. Heilborn ML, Aquino EML, Bozon M, Knauth DR. O aprendizado da sexualidade: reprodução e trajetórias sociais de jovens brasileiros. Rio de Janeiro (RJ): Ed. Garamond e Fiocruz; 2006.

8. Ministério da Saúde (BR). Secretaria de Saúde da Cidade de São Paulo. Manual de atenção à saúde do adolescente. São Paulo (SP): Coordenação de Desenvolvimento de Programas e Políticas de Saúde; 2006.

9. Gama SGN, Szwarcwald CL, Sabroza AR, Branco VC, Leal MC. Fatores associados à assistência pré-natal precária em uma amostra de puérperas adolescentes em maternidades do Município do Rio de Janeiro, 1999-2000. Cad Saúde Pública. 2004; 20(sup1):101-11. 
10. Trevisan MR, Lorenzi DRS, Araújo NM, Ésber K. Perfil da assistência pré-natal entre usuárias do Sistema Único de Saúde em Caxias do Sul. Rev Bras Ginecol Obstet. 2002 24(5):293-99.

11. Chalem E, Mitsuhiro SS, Ferri CP, Barros MCM, Guinsburg R, Laranjeira R. Gravidez na adolescência: perfil sócio-demográfico e comportamental de uma população da periferia de São Paulo, Brasil. Cad Saúde Pública. 2007 Jan; 23(1):177-86.

12. Persona L, Shimo AKK, Tarallo MC. Perfil de adolescentes com repetição da gravidez atendidas num ambulatório de pré-natal. Rev Latino-Am Enfermagem. 2004 Set-Out; 12(5):745-50.

13. Spindola T, Silva LFF. Perfil epidemiológico de adolescentes atendidas no pré-natal de um hospital universitário. Esc Anna Nery Rev Enferm. 2009 JanMar; 13(1):99-107.

14. Gigante DP, Barros FC, Veleda R, Gonçalves H, Horta BL, Victora CG. Maternidade e paternidade na coorte de nascimentos de 1982 a 2004-5, Pelotas, RS. Rev Saúde Pública. 2008; 42(supl.2):42-50.

15. Baraldi ACP, Daud ZP, Almeida AM, Gomes FA, Nakano AMS. Gravidez na adolescência: estudo comparativo das usuárias das maternidades públicas e privadas. Rev Latino-Am Enfermagem [online]. 2007 [acesso 2012 Nov 17]; 15(esp).

Disponível em: www.eerp.usp.br/rlae

16. Serruya SJ, Cecatti JG, Lago TG. O Programa de Humanização no Pré-natal e Nascimento do Ministério da Saúde no Brasil: resultados iniciais. Cad Saúde Pública. 2004 Set-Out; 20(5):1281-9.

17. Silveira DS, Santos IS, Costa JSD. Atenção prénatal na rede básica: uma avaliação da estrutura e do processo. Cad. Saúde Pública. 2001 Jan-Fev; 17(1):131-9.

18. Domingues RMSM, Santos EM, Leal MC. Aspectos da satisfação das mulheres com a assistência ao parto: contribuição para o debate. Cad Saúde Pública. 2004; 20(supl. 1):52-62.

19. Landerdahl MC, Ressel LB, Martins FB, Cabral FB, Gonçalves MO. A percepção de mulheres sobre atenção pré-natal em uma Unidade Básica de Saúde. Esc Anna Nery Rev Enfermagem. 2007 Mar; 11(1):105-11.

20. Sodré TM, Bonadio IC, Jesus MCP, Merighi MAB. Necessidade de cuidado e desejo de participação no parto de gestantes residentes em Londrina-Paraná. Texto Contexto Enferm. 2010 Jul-Set; 19(3):452-60. 